Article

\title{
Chemical Composition and Nematicidal Activity of Essential Oil of Agastache rugosa against Meloidogyne incognita
}

\author{
He Qin Li ${ }^{1}$, Qi Zhi Liu ${ }^{1}$, Zhi Long Liu ${ }^{1, *}$, Shu Shan Du ${ }^{2, *}$ and Zhi Wei Deng ${ }^{3}$
}

1 Department of Entomology, China Agricultural University, Haidian District, Beijing 100193, China; E-Mails: hqliaau@163.com (H.Q.L.); lqzwyz@cau.edu.cn (Q.Z.L.)

2 College of Resources Science and Technology, Beijing Normal University, Haidian District, Beijing 100875, China

3 Analytic and Testing Center, Beijing Normal University, Haidian District, Beijing 100875, China; E-Mail: dengzw@bnu.edu.cn

* Authors to whom correspondence should be addressed; E-Mails: zhilongliu@cau.edu.cn (Z.L.L.); dushushan@bnu.edu.cn (S.S.D.); Tel./Fax: +86-10-6273-2800 (Z.L.L.);

Tel./Fax: +86-10-6220-8032 (S.S.D.).

Received: 26 February 2013; in revised form: 2 April 2013 / Accepted: 3 April 2013 /

Published: 9 April 2013

\begin{abstract}
The aim of this research was to determine the chemical composition and nematicidal activity of essential oil of Agastache rugosa flowering aerial parts against the root knot nematode, Meloidogyne incognita, and to isolate and identify any nematicidal constituents from the essential oil. The essential oil of A. rugosa aerial parts was obtained by hydrodistillation and analyzed by GC-FID and GC-MS. A total of 37 components of the essential oil were identified, with the principal compounds being methyleugenol $(50.51 \%)$, estragole $(8.55 \%)$, and eugenol (7.54\%), followed by thymol $(3.62 \%)$, pulegone $(2.56 \%)$, limonene $(2.49 \%)$ and caryophyllene $(2.38 \%)$. Based on bioactivity-guided fractionation, the three active constituents were isolated from the essential oil and identified as methyleugenol, estragole and eugenol. The essential oil of A. rugosa exhibited strong nematicidal activity against $M$. incognita, with a $\mathrm{LC}_{50}$ value of $47.3 \mu \mathrm{g} / \mathrm{mL}$. The components eugenol $\left(\mathrm{LC}_{50}=66.6 \mu \mathrm{g} / \mathrm{mL}\right)$ and methyleugenol $\left(\mathrm{LC}_{50}=89.4 \mu \mathrm{g} / \mathrm{mL}\right)$ exhibited stronger nematicidal activity against $M$. incognita $\left(\mathrm{LC}_{50}=185.9 \mu \mathrm{g} / \mathrm{mL}\right)$. The results indicate that the essential oil of $A$. rugosa aerial parts and its constituent compounds have potential for development into natural nematicides for control of the root knot nematode.
\end{abstract}


Keywords: Agastache rugosa; Meloidogyne incognita; essential oil composition; methyleugenol; estragole; eugenol

\section{Introduction}

Nematodes are tiny worms, some of them are parasites to plants, and can play an important role in the predisposition of the host plant to invasions by secondary pathogens. Meloidogyne incognita (Kofoid and White) Chitwood is the most economically important and widely distributed nematode throughout China and it is responsible for considerable crop losses [1]. Essential oils from different plant sources have demonstrated several biological activities, including antibacterial and antifungal [2,3], insecticidal [4-6], larvicidal [7-9], acaricidal [10], and nematicidal [1,11-16]. As a consequence, this vast arsenal of bioactive compounds has attracted significant and increasing attention of researchers in recent years [17-20]. During our mass screening program for new agrochemicals from local wild plants and Chinese medicinal herbs, the essential oil from Agastache rugosa (Fisch. et Mey.) Kuntze (family: Labiatae) flowering aerial parts has been found to possess nematicidal activity towards the root knot nematode, $M$. incognita.

A. rugosa has been used as a wild vegetable and herbal drug for the treatment of anorexia, vomiting and other intestinal disorders [21]. Chemical composition of the essential oils obtained from aerial parts (stem, flower, leaves) of A. rugosa grown in different countries has been the subject of some studies and a great variation in chemical composition of the essential oils were observed [22-36]. This plant has been proved to have antimicrobial [26,32], anti-fungal [30,31] and antiviral activity [28]. Methanol extract of A. rugosa whole plant possessed strong insecticidal activity against the cigarette beetle (Lasioderma serricorne) [37] and adults of the rice weevil (Sitophilus oryzae) and the adzuki bean weevil (Callosobruchus chinensis) [38]. However, a literature survey has shown that there are no reports on the nematidicidal activity of $A$. rugosa essential oil against root-knot nematodes, thus we decided to investigate for the first time the chemical constituents and nematicidal activity of the essential oil of A. rugosa against this species and to isolate any active constituent compounds from the essential oil.

\section{Results and Discussion}

\subsection{Essential Oil Chemical Composition}

The yield of $A$. rugosa essential oil was $0.32 \%(\mathrm{v} / \mathrm{w})$ and the density of the essential oil was determined to be $0.91 \mathrm{~g} / \mathrm{mL}$. GC-MS analysis of the essential oil of $A$. rugosa aerial parts led to the identification and quantification of a total of 37 major components, accounting for $96.14 \%$ of the total components present (Table 1). The principal compounds in the essential oil of A. rugosa were methyleugenol $(50.51 \%)$, estragole $(8.55 \%)$, and eugenol $(7.54 \%)$ (Figure 1$)$, followed by thymol (3.62\%), pulegone (2.56\%), limonene $(2.49 \%)$ and caryophyllene $(2.38 \%)$. Most of the essential oil was phenylpropanoids (66.60\%) and only $14.22 \%$ monoterpenoids and $13.34 \%$ sesquiterpenoids. The results are quite different from the previous reports. For example, estragole (ranging from 46.7 to 93.7\%) was major compound of the essential oils of A. rugosa and A. foeniculum and putative hybrids 
collected from North America [22,39]. Moreover, the essential oils of A. rugosa collected from Europe [23,24], Vietnam [25], and Korea [28-30] all contained estragole as a principal compound.

Table 1. Chemical constituents of the essential oil derived from Agastache rugosa aerial parts.

\begin{tabular}{|c|c|c|}
\hline RI * & Compound & Composition, \% \\
\hline Monoterpenoids & & 14.22 \\
\hline 931 & $\alpha$-Pinene & 0.52 \\
\hline 984 & $\beta$-Pinene & 1.21 \\
\hline 1029 & D-Limonene & 2.49 \\
\hline 1057 & $\gamma$-Terpinene & 0.13 \\
\hline 1188 & $\alpha$-Terpineol & 0.34 \\
\hline 1097 & Linalool & 1.77 \\
\hline 1236 & Pulegone & 2.56 \\
\hline 1288 & Cuminic alcohol & 1.38 \\
\hline 1292 & Thymol & 3.62 \\
\hline Sesquiterpenoids & & 13.34 \\
\hline 1313 & Elixene & 0.12 \\
\hline 1317 & Carvacrol & 0.20 \\
\hline 1350 & $\alpha$-Cubebene & 0.13 \\
\hline 1382 & iso-Ledene & 0.11 \\
\hline 1385 & $\beta$-Bourbonene & 0.37 \\
\hline 1393 & $\beta$-Elemen & 0.26 \\
\hline 1420 & Caryophyllene & 2.38 \\
\hline 1462 & cis- $\alpha$-Farnesene & 0.17 \\
\hline 1473 & $\gamma$-Muurolene & 0.41 \\
\hline 1486 & Germacrene D & 1.45 \\
\hline 1491 & Aromadendrene & 0.32 \\
\hline 1499 & Bicyclogermacrene & 0.88 \\
\hline 1500 & $\alpha$-Muurolene & 0.29 \\
\hline 1511 & $\alpha$-Farnesene & 0.72 \\
\hline 1454 & $\alpha$-Caryophyllene & 0.19 \\
\hline 1521 & $\delta$-Cadinene & 0.85 \\
\hline 1546 & Cadina-4,9-diene & 0.28 \\
\hline 1561 & Germacrene B & 0.68 \\
\hline 1578 & Spatulenol & 1.11 \\
\hline 1584 & Caryophyllene oxide & 0.73 \\
\hline 1592 & Viridiflorol & 0.12 \\
\hline 1642 & $\tau$-Muurolol & 0.81 \\
\hline 1652 & $\alpha$-Cadinol & 0.96 \\
\hline Phenylpropanoids & & 66.60 \\
\hline 1195 & Estragole & 8.55 \\
\hline 1356 & Eugenol & 7.54 \\
\hline 1369 & Methyleugenol & 50.51 \\
\hline Others & & 1.98 \\
\hline 975 & Morrilol & 0.16 \\
\hline 1066 & Acetophenone & 1.82 \\
\hline Total identified & & 96.14 \\
\hline
\end{tabular}

* RI, retention index as determined on a HP-5MS column using the homologous series of $n$-hydrocarbons. 
Figure 1. Constituent compounds isolated from the essential oil of Agastache rugosa aerial parts.

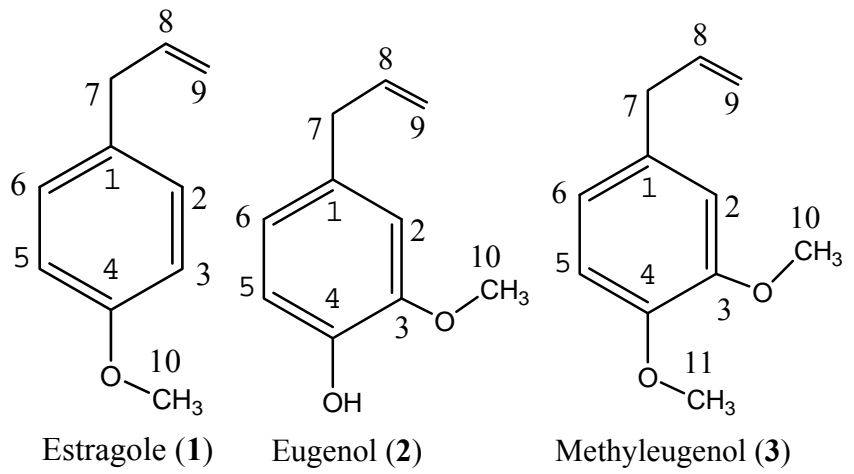

On the other hand, thymoquinone $(70.11 \%)$ was the main component of the essential oil of A. rugosa aerial parts collected from northeast China [40], while estragole (74.84\%) was the major compound of the essential oil of A. rugosa aerial parts collected from Hubei Province (Central China) and methyleugenol (49.89\%) and estragole (19.45\%) were two major compounds of the essential oil of A. rugosa aerial parts collected from Henan Province (Central China) [41]. Pulegone (37.58\%) was the principal component of the essential oil of A. rugosa aerial parts collected from Zhejiang Province (Eastern China) [42]. Three chemoecological types of A. rugosa were consequently suggested as follows: type A with estragole as the main constituent, type B with methyleugenol as the principal constituent and type $\mathrm{C}$ with menthone derivates as the major constituents [43]. It seems that all the three chemotypic races of this species of plant are found in China. Our samples (from Beijing) belong to type B, with about $50 \%$ methyleugenol as the principal compound (Table 1), whereas samples collected from Central China belong to type A or type B [41]. Moreover, samples collected from Eastern China and Northeast China do not belong to any of the three types [40,42] because the major constituent compounds in those essential oils were thymoquinone and pulegone, respectively. Thus, further studies are needed to clarify variation of constituents of the Chinese A. rugosa oil. However, all these differences of chemical composition of the essential oils might have been due to harvest time and local, climatic and seasonal factors, as well as storage duration of the medicinal herbs. For practical use, it would be necessary to standardize the essential oil of Chinese A. rugosa.

\subsection{Nematicidal Activity}

The essential oil of $A$. rugosa aerial parts exhibited strong nematicidal activity against root knot nematode, $M$. incognita, with an $\mathrm{LC}_{50}$ value of $47.3 \mu \mathrm{g} / \mathrm{mL}$ (Table 2). Compared with the synthetic insecticide carbofuran, the essential oil of $A$. rugosa aerial parts possessed stronger toxicity against M. incognita, as carbofuran displayed a $\mathrm{LC}_{50}$ value of $72.3 \mu \mathrm{g} / \mathrm{mL}$ [1]. Among the three main components, both eugenol $\left(\mathrm{LC}_{50}=66.6 \mu \mathrm{g} / \mathrm{mL}\right)$ and methyleugenol $\left(\mathrm{LC}_{50}=89.4 \mu \mathrm{g} / \mathrm{mL}\right)$ exhibited stronger nematicidal activity against $M$. incognita than estragole $\left(\mathrm{LC}_{50}=185.9 \mu \mathrm{g} / \mathrm{mL}\right)$. Compared with carbofuran, eugenol and methyleugenol exhibited a stronger or similar level of nematicidal activity towards $M$. incognita. In previous reports [44-47], eugenol and methyleugenol have been demonstrated to possess nematicidal activity against several nematode species, e.g., pine wood nematode (Bursaphelenchus xylophilus), Caenorhabditis elegans, and root knot nematode, $M$. incognita. However, all the three isolated constituent compounds possessed less activity against the root knot 
nematode than the crude essential oil (Table 2), suggesting that there may be stronger active compound(s) in small amounts in the essential oil or maybe some synergistic action between the various compounds. For example, carvacrol and thymol immobilized the juveniles of the root knot nematode $M$. javanica and inhibited hatching at $>125 \mu \mathrm{L} / \mathrm{L}$ in vitro and the two components mixed in sandy soil at concentrations of 75 and $150 \mathrm{mg} / \mathrm{kg}$ reduced root galling of cucumber seedlings [17]. Carvacrol and thymol exhibited nematicidal activity against root knot nematode, $M$. incognita, with $76 \mathrm{~h}$ $\mathrm{LC}_{50}$ values of $176 \mu \mathrm{g} / \mathrm{mL}$ and $280 \mu \mathrm{g} / \mathrm{mL}$, respectively [45]. In previous reports, a synergistic effect among terpene constituents of the essential oils from seven plants indigenous to Greece has been detected $[18,46]$. The most potent terpene pairs between which synergistic actions were found, in decreasing order, were: trans-anethole/geraniol, trans-anethole/eugenol, carvacrol/eugenol and geraniol/carvacrol.

Table 2. Nematicidal activity of the essential oil of Agastache rugosa aerial parts and its three main components against Meloidogyne incognita.

\begin{tabular}{|c|c|c|c|c|c|}
\hline Treatments & $\begin{array}{c}\text { Concentrations } \\
(\mu \mathrm{g} / \mathrm{mL})\end{array}$ & $\begin{array}{c}\mathrm{LC}_{50}(\mu \mathrm{g} / \mathrm{mL}) \\
95 \% \mathrm{FL} *\end{array}$ & $\begin{array}{c}\mathrm{LC}_{90}(\mu \mathrm{g} / \mathrm{mL}) \\
95 \% \mathrm{FL} *\end{array}$ & Slope \pm SE & $\begin{array}{c}\text { Chi square } \\
\left(\chi^{2}\right)\end{array}$ \\
\hline A. rugosa & $12.5-200.0$ & $\begin{array}{c}47.3 \\
(42.9-55.2)\end{array}$ & $\begin{array}{c}174.6 \\
(156.9-191.1)\end{array}$ & $6.51 \pm 0.66$ & 9.06 \\
\hline Estragole & $80.0-860.0$ & $\begin{array}{c}185.9 \\
(169.7-206.1)\end{array}$ & $\begin{array}{c}463.6 \\
(422.9-489.5)\end{array}$ & $7.03 \pm 0.68$ & 7.64 \\
\hline Eugenol & $12.5-200.0$ & $\begin{array}{c}66.6 \\
(60.6-74.1)\end{array}$ & $\begin{array}{c}182.3 \\
(164.8-198.6)\end{array}$ & $5.21 \pm 0.53$ & 9.77 \\
\hline Methyleugenol & $40.0-240.0$ & $\begin{array}{c}89.4 \\
(79.7-98.1)\end{array}$ & $\begin{array}{c}193.7 \\
(176.7-214.9)\end{array}$ & $8.36 \pm 0.78$ & 8.25 \\
\hline Carbofuran ** & $25.0-400.0$ & $\begin{array}{c}72.3 \\
(37.9-118.0)\end{array}$ & - & - & 13.57 \\
\hline
\end{tabular}

* Fiducial limits; ** From Bai et al. [11].

Andres et al. [18] also demonstrated that there was a synergistic interaction between some of the constituent compounds (carvone, 1,8-cineole and menthol) at certain concentrations. Considering the positive control is a synthetic insecticide, the observed nematicidal activity of the essential oil of A. rugosa and the three constituent compounds, especially eugenol and methyleugenol, is quite promising and the essential oil and its individual constituents show potential to be developed as possible natural nematicides for the control of the root knot nematodes, although for the practical application of the essential oil and the isolated constituent compounds as novel nematicides, further studies on the safety of the essential oil/pure compounds to humans and on development of formulations are necessary to improve the efficacy and stability and to reduce cost.

\section{Experimental}

\subsection{Plant Material and Essential Oil Extraction}

Fresh aerial parts (10 kg of leaves, stems and flowers) of A. rugosa were harvested in August 2009 from Xiaolongmeng National Forest Park (Mentougou District, Beijing 102300, 38.24 $\mathrm{N}$ latitude and 
$115.20^{\circ}$ E longitude). The species was identified by Dr. Liu, QR (College of Life Sciences, Beijing Normal University, China), and the voucher specimen (CMH-TuHuoXiang-Beijing-2009-08) was deposited in the museum of Department of Entomology, China Agricultural University. The aerial parts were air-dried for one week and ground to a powder using a grinding mill (Retsch Muhle, Germany). The powder was subjected to hydrodistillation using a modified Clevenger-type apparatus for $6 \mathrm{~h}$ and extracted with $n$-hexane. Anhydrous sodium sulphate was used to remove water after extraction. The essential oil was stored in airtight containers in a refrigerator at $4{ }^{\circ} \mathrm{C}$ for subsequent experiments.

\subsection{Gas Chromatography-Mass Spectrometry}

Components of the essential oil of A. rugosa aerial parts were separated and identified by gas chromatography-flame ionization detection (GC-FID) and gas chromatography-mass spectrometry (GC-MS) using an Agilent 6890N gas chromatography system connected to an Agilent 5973N mass selective detector. The same column and analysis conditions were used for both GC-FID and GC-MS. They were equipped with capillary column with HP-5MS $(30 \mathrm{~m} \times 0.25 \mathrm{~mm} \times 0.25 \mu \mathrm{m})$. The GC settings were as follows: the initial oven temperature was held at $60{ }^{\circ} \mathrm{C}$ for $1 \mathrm{~min}$ and ramped at $10^{\circ} \mathrm{C} \mathrm{min}{ }^{-1}$ to $180{ }^{\circ} \mathrm{C}$ where it was held for $1 \mathrm{~min}$, and then ramped at $20{ }^{\circ} \mathrm{C} \mathrm{min}{ }^{-1}$ to $280{ }^{\circ} \mathrm{C}$ and held there for $15 \mathrm{~min}$. The injector temperature was maintained at $270{ }^{\circ} \mathrm{C}$. The samples $(1 \mu \mathrm{L}$, after diluted to $1 \%$ with acetone) were injected, with a split ratio of 1: 10. The carrier gas was helium at flow rate of $1.0 \mathrm{~mL} \mathrm{~min}{ }^{-1}$. Spectra were scanned from 20 to $550 \mathrm{~m} / \mathrm{z}$ at 2 scans s${ }^{-1}$. Most constituents were identified by gas chromatography by comparison of their retention indices with those of the literature or with those of authentic compounds available in our laboratories. The retention indices were determined in relation to a homologous series of $n$-alkanes $\left(\mathrm{C}_{8}-\mathrm{C}_{24}\right)$ under the same operating conditions. Further identification was made by comparison of their mass spectra with those stored in NIST 05 and Wiley 275 libraries or with mass spectra from the literature [48]. Relative percentages of the individual components of the essential oil were obtained by averaging the GC-FID peak area\% reports.

\subsection{Purification and Characterization of Three Constituent Compounds}

The crude essential oil of $A$. rugosa aerial parts $(25 \mathrm{~mL})$ was chromatographed on a silica gel (Merck 9385, 1,000 g) column ( $85 \mathrm{~mm}$ i.d., $850 \mathrm{~mm}$ length) by gradient elution with a mixture of solvents ( $n$-hexane, $n$-hexane-ethyl acetate). Fractions of $500 \mathrm{~mL}$ were collected and concentrated at $40{ }^{\circ} \mathrm{C}$, and similar fractions according to their TLC profiles were combined to yield 15 fractions. Fractions 5-8, 10, 12 that possessed nematicidal toxicity, and with similar TLC profiles, were pooled and further purified by preparative silica gel column chromatography (PTLC) with petroleum ether-acetone $(50: 1, \mathrm{v} / \mathrm{v})$ until to obtain the pure compounds for determining their structures based on nuclear magnetic resonance spectroscopy. ${ }^{1} \mathrm{H}$ and ${ }^{13} \mathrm{C}$-NMR spectra were recorded on a Bruker AMX500 $\left[500 \mathrm{MHz}\left({ }^{1} \mathrm{H}\right)\right]$ instrument using $\mathrm{CDCl}_{3}$ as the solvent with TMS as internal standard. Electron impact mass spectra (EIMS) were determined on a Micromass VG7035 mass spectrometer at $70 \mathrm{eV}$ (probe). 


\subsection{Isolated Constituent Compounds}

Estragole (1, Figure 1). A colorless oil $(0.3 \mathrm{~g}), \mathrm{C}_{10} \mathrm{H}_{12} \mathrm{O} .{ }^{1} \mathrm{H}-\mathrm{NMR}\left(\mathrm{CDCl}_{3}\right) \delta(\mathrm{ppm}): 7.27(1 \mathrm{H}, \mathrm{d}, \mathrm{H}-3$, 5), $7.01(1 \mathrm{H}, \mathrm{d}, \mathrm{H}-2,6), 6.14(1 \mathrm{H}, \mathrm{m}, \mathrm{H}-8), 5.26(2 \mathrm{H}, \mathrm{d}, \mathrm{H}-9), 3.92\left(3 \mathrm{H}, \mathrm{s}, 10-\mathrm{CH}_{3}\right), 3.50$ (2H, d, H-7). ${ }^{13} \mathrm{C}-\mathrm{NMR}\left(125 \mathrm{MHz}, \mathrm{CDCl}_{3}\right) \delta(\mathrm{ppm}): 158.22$ (C-8), 138.08 (C-1), 132.16 (C-9), 129.61 (C-4), 115.52 (C-3, C-5), 113.99 (C-2, C-6), 55.18(C-10), 39.52 (C-7). EI-MS m/z (\%): 149 (13), 148 (100), 147 (46), 133 (23), 121 (41), 117 (32), 105 (23), 91 (20), 77 (23). The spectral data matched that given in a previous report [6].

Eugenol (2, Figure 1). A colorless oil $(0.4 \mathrm{~g}), \mathrm{C}_{10} \mathrm{H}_{12} \mathrm{O}_{2} .{ }^{1} \mathrm{H}-\mathrm{NMR}\left(\mathrm{CDCl}_{3}\right) \delta(\mathrm{ppm}): \delta: 6.83(1 \mathrm{H}, \mathrm{d}$, $J=8.8 \mathrm{~Hz}, \mathrm{H}-5), 6.66(1 \mathrm{H}, \mathrm{dd}, J=8.4,1.8 \mathrm{~Hz}, \mathrm{H}-6), 6.65(1 \mathrm{H}, \mathrm{d}, J=1.8 \mathrm{~Hz}, \mathrm{H}-2), 5.94(1 \mathrm{H}, \mathrm{m}, \mathrm{H}-8)$, $5.73\left(1 \mathrm{H}\right.$, br.s, $\mathrm{D}_{2} \mathrm{O}$ exchangeable, $\left.-\mathrm{OH}\right), 5.06(2 \mathrm{H}, \mathrm{m}, \mathrm{H}-9), 3.81\left(3 \mathrm{H}, \mathrm{s},-\mathrm{OCH}_{3}\right), 3.30(2 \mathrm{H}, \mathrm{dt}, J=6.6$, $1.5 \mathrm{~Hz}, \mathrm{H}-7) .{ }^{13} \mathrm{C}-\mathrm{NMR}\left(125 \mathrm{MHz}, \mathrm{CDCl}_{3}\right) \delta(\mathrm{ppm}): 146.60$ (C-3), 144.03 (C-4), 137.91 (C-8), 131.94 (C-1), 115.49 (C-5), 114.46 (C-2), 111.26 (C-9), 55.84 (C-10), 39.92 (C-7). EI-MS m/z (\%): 165 (11), 164 (100), 149 (29), 137 (15), 133 (15), 121 (14), 103 (19), 91 (14), 77 (21), 55 (18). The spectral data matched that given in a previous report [49].

Methyleugenol (3, Figure 1). A colorless oil $(0.8 \mathrm{~g}), \mathrm{C}_{11} \mathrm{H}_{14} \mathrm{O}_{2} .{ }^{1} \mathrm{H}-\mathrm{NMR}\left(\mathrm{CDCl}_{3}\right) \delta(\mathrm{ppm}): 6.81(1 \mathrm{H}, \mathrm{d}$, $J=8.0, \mathrm{H}-6), 6.74(1 \mathrm{H}, \mathrm{dd}, J=8.0,2.0, \mathrm{H}-5), 6.71(1 \mathrm{H}, \mathrm{d}, J=2.0 \mathrm{H}-2), 5.96$ (1H, ddt, $J=17.0,10.4$, 6.8, H-8), $5.07(2 \mathrm{H}, \mathrm{m}, \mathrm{H}-9), 3.86\left(3 \mathrm{H}, \mathrm{s},-\mathrm{OCH}_{3}\right), 3.87\left(3 \mathrm{H}, \mathrm{s},-\mathrm{OCH}_{3}\right), 3.34(2 \mathrm{H}$, ddd, $J=6.8,1.7$, 1.4, H-7). ${ }^{13} \mathrm{C}-\mathrm{NMR}\left(125 \mathrm{MHz}, \mathrm{CDCl}_{3}\right) \delta(\mathrm{ppm}): 148.8(\mathrm{C}-4), 147.3(\mathrm{C}-3), 137.7$ (C-8), $132.6(\mathrm{C}-6)$, 120.4 (C-1), 115.6 (C-9), 111.8 (C-2), $111.2(\mathrm{C}-5), 55.9\left(-\mathrm{OCH}_{3}\right), 55.7\left(-\mathrm{OCH}_{3}\right), 39.8$ (C-7). EI-MS m/z (\%): 178 (100), 163 (33), 151 (15), 147 (32), 135 (18), 131 (11), 107 (28), 103 (39), 91 (50), 77 (26). The spectra data matched with previous report [50].

\subsection{Nematicidal Assay}

Egg masses of $M$. incognita obtained from tomato roots with aid of a stereomicroscope were maintained in Petri dishes during $24 \mathrm{~h}$ in distilled $\mathrm{H}_{2} \mathrm{O}$ for the juveniles to hatch. Range-finding studies were run to determine the appropriate testing concentrations. A serial dilution of A. rugosa essential oil (five concentrations) and pure compounds (five concentrations) was prepared in $\mathrm{H}_{2} \mathrm{O}$ solution with $2 \%$ DMSO. Aliquots of $\mathrm{H}_{2} \mathrm{O}(20 \mu \mathrm{L})$ containing ca. 100 juveniles $\left(\mathrm{J}_{2}\right)$ were transferred to vials to which $980 \mu \mathrm{L}$ of the solution containing essential oil or pure compounds was added. The vials were kept in a hood at $25^{\circ} \mathrm{C}$. The counting of the inactive nematodes was performed at every $24 \mathrm{~h}$ for $72 \mathrm{~h}$. After the last count, the inactive juveniles were maintained in distilled $\mathrm{H}_{2} \mathrm{O}$ for $24 \mathrm{~h}$ to observe their revival. Six repetitions for each treatment were performed using $\mathrm{H}_{2} \mathrm{O}$ and a $\%$ DMSO in $\mathrm{H}_{2} \mathrm{O}$ solution as control. The experiments were repeated in three times. Results from all replicates for the pure compounds and essential oil were subjected to probit analysis using the PriProbit Program V1.6.3 to determine LC $_{50}$ (median lethal concentration) values and their 95\% confidence intervals (CI 95\%) [51]. 


\section{Conclusions}

The study indicates that the essential oil of A. rugosa aerial parts and its main constituent compounds, eugenol, methyleugenol and estragole, have potential for development into natural nematicides for the control of root knot nematodes.

\section{Acknowledgments}

This project was supported by the Hi-Tech Research and Development of China 2011AA10A202. We thank Liu Q.R. from the College of Life Sciences, Beijing Normal University, Beijing 100875, for the identification of the investigated plants.

\section{References}

1. Bai, C.Q.; Liu, Z.L.; Liu, Q.Z. Nematicidal constituents from the essential oil of Chenopodium ambrosioides aerial parts. E-J. Chem. 2011, 8, 143-148.

2. Wang, J.H.; Zhao, J.L.; Liu, H.; Zhou, L.; Liu, Z.L.; Han, J.G.; Zhu, Y.; Yang, F.Y. Chemical analysis and biological activity of the essential oils of two Valerianaceous species from China: Nardostachys chinensis and Valeriana. officinalis. Molecules 2010, 15, 6411-6422.

3. Wang, J.H.; Xu, L.; Yang, L.; Liu, Z.L.; Zhou, L. Composition, antibacterial and antioxidant activities of essential oils from Ligusticum sinense and L. jeholense (Umbelliferae) from China. Rec. Nat. Prod. 2011, 5, 314-318.

4. Chu, S.S.; Hu, J.F.; Liu, Z.L. Composition of essential oil of Chinese Chenopodium ambrosioides and insecticidal activities to maize weevil, Sitophilus zeamais. Pest. Manag. Sci. 2011, 67, 714-718.

5. Chu, S.S.; Jiang, G.H.; Liu, Z.L. Insecticidal compounds from the essential oil of Chinese medicinal herb, Atractylodes chinensis. Pest. Manag. Sci. 2011, 67, 1253-1257.

6. Zhao, N.N.; Zhou, L.; Liu, Z.L.; Du, S.S.; Deng, Z.W. Evaluation of toxicities of some common spices essential oils from China against Liposcelis bostrychophila. Food Control. 2012, 26, 486-490.

7. Liu, Z.L.; He, Q.; Chu, S.S.; Wang, C.F.; Du, S.S.; Deng, Z.W. Essential oil composition and larvicidal activity of Saussurea lappa roots against the mosquito Aedes albopictus (Diptera: Culicidae). Parasitol. Res. 2012, 110, 2125-2130.

8. Liu, Z.L.; Liu, Q.Z.; Du, S.S.; Deng, Z.W. Mosquito larvicidal activity of alkaloids and limonoids derived from Evodia rutaecarpa unripe fruits against Aedes albopictus (Diptera: Culicidae). Parasitol. Res. 2012, 111, 991-996.

9. Liu, X.C., Dong, H.W.; Zhou, L.; Du, S.S.; Liu, Z.L. Essential oil composition and larvicidal activity of Toddalia asiatica roots against the mosquito Aedes albopictus (Diptera: Culicidae). Parasitol. Res. 2013, doi:10.1007/s00436-012-3251-9.

10. Sung, B.K.; Lee, H.S. Chemical composition and acaricidal activities of constituents derived from Eugenia caryophyllata leaf oils. Food Sci. Biotechnol. 2005, 14, P73-P76.

11. Li, H.Q.; Bai, C.Q.; Chu, S.S.; Zhou, L.; Du, S.S.; Liu, Z.L.; Liu, Q.Z. Chemical composition and toxicities of the essential oil derived from Kadsura heteroclita stems against Sitophilus zeamais and Meloidogyne incognita. J. Med. Plants Res. 2011, 5, 4943-4948. 
12. Liu, Q.Z.; Li, H.Q.; Liu, Z.L. Nematicidal constituents from the ethanol extract of Evodia rutaecarpa Hort unripe fruits. J. Chem. 2013, doi:10.1155/2013/939215.

13. Lahlou, M. Methods to study the phytochemistry and bioactivity of essential oils. Phytother. Res. 2004, 18, 435-448.

14. Ntalli, N.G.; Manconi, F.; Leonti, M.; Maxia, A.; Caboni, P. Aliphatic ketones from Ruta chalepensis (Rutaceae) induce paralysis on root knot nematodes. J. Agric. Food Chem. 2011, 59, 7098-7103.

15. Oka, Y.; Nacar, S.; Putievsky, E.; Ravid, U.; Yaniv, Z.; Spiegel, Y. Nematicidal activity of essential oils and their components against the root-knot nematode. Phytopathology 2000, 90, $710-715$.

16. Al-Banna, L.; Darwish, R.M.; Aburjai, T. Effect of plant extracts and EOs on root-knot nematode. Phytopathol. Mediterr. 2003, 42, 123-128.

17. Ntalli, N.G.; Caboni, P. Botanical nematicides: A review. J. Agric. Food Chem. 2012, 60, 9929-9940.

18. Andres, M.F.; Gonzalez-Coloma, A.; Sanz, J.; Burillo J.; Sainz, P. Nematicidal activity of essential oils: A review. Phytochem. Rev. 2013, doi:10.1007/s11101-012-9263-3.

19. Isman, M.B. Plant essential oils for pest and disease management. Crop. Prot. 2000, 19, 603-608.

20. Isman, M.B. Botanical insecticides, deterrents, and repellents in modern agriculture and an increasingly regulated world. Ann. Rev. Entomol. 2006, 51, 45-66.

21. Jinagsu New Medical College. Dictionary of Chinese Herbal Medicine; Shanghai Science \& Technology Press: Shanghai, China, 1977; pp. 2710-2712.

22. Charles, D.J.; Simon, J.E; Widrlechner, M.P. Characterization of the essential oil of Agastache species. J. Agric. Food Chem. 1991, 39, 1946-1949.

23. Weyerstahl, P.; Marschall, H.; Manteuffel, E. Volatile constituents of Agastache rugosa. J. Essent. Oil Res. 1992, 4, 585-587.

24. Svoboda, K.P.; Gough, J.; Hampson, J.; Galambosi, B. Analysis of the essential oils of some Agastache. species grown in Scotland from various seed sources. Flav. Fragr. J. 1995, 10, 139-145.

25. Nguyen, X.D.; Luu, D.C.; Nguyen, H.T.; La, D.M.; Le, V.H.; Leclercq, P.A. Constituents of the leaf and flower oils of Agastache rugosa (Fisch. et Mey) O. Kuntze from Vietnam. J. Essent. Oil Res. 1996, 8, 135-138.

26. Song, J.H.; Kim, M.J.; Kwon, H.D.; Lee, W.K.; Park I.H. Antimicrobial activity and characterization of volatile flavor extracts from Agastache rugosa. J. Food Sci. Nutr. 1999, 4, 97-102.

27. Yang, D.; Wang, F.; Su, J.; Zeng, L. Chemical composition of essential oil in stems, leaves and flowers of Agastache rugosa. J. Chin. Med. Mater. 2000, 23, 149-151.

28. Kim, T.H.; Shin, J.H.; Baek, H.H.; Lee, H.J. Volatile flavour compounds in suspension culture of Agastache rugosa Kuntze (Korean mint). J. Sci. Food Agric. 2001, 81, 569-575.

29. Shin, S.; Kim, Y.S.; Kang, C.A. Production of volatile oil components by cell culture of Agastache rugosa O. Kuntze. Nat. Prod. Sci. 2001, 7, 120-123.

30. Shin, S.; Kang, C.A. Antifungal activity of the essential oil of Agastache rugosa Kuntze and its synergism with ketoconazole. Lett. Appl. Microbiol. 2003, 36: 111-115. 
31. Shin, S. Essential oil compounds from Agastache rugosa as antifungal agents against Trichophyton species. Arch. Pharm. Res. 2004, 27, 295-299.

32. Chae, Y.A.; Hyun-Choong, O.; Song, J.S. Variability of the volatile composition of Agastache rugosa in South Korea. Acta. Hort. 2005, 675, 59-64.

33. Kim, J. Phytotoxic and antimicrobial activities and chemical analysis of leaf essential oil from Agastache rugosa. J. Plant. Biol. 2008, 51, 276-283.

34. Skakovskii, E.D.; Kiselev, W.P.; Tychinskaya, L.Y; Schutova, A.G.; Gonsharova, L.W.; Spiridowish, E.W.; Bovdey, N.A.; Kiselev, P.A.; Gaidukevich, O.A. Characterization of the essential oil of Agastache rugosa by NMR spectroscopy. J. Appl. Spectrosc. 2010, 77, 329-334.

35. Jun, H.J.; Chung, M.J.; Dawson, K.; Rodriguez, R.L.; Houng, S.J.; Cho, S.Y.; Jeun, J.; Kim, J.Y.; Kim, K.H.; Park, K.W. Nutrigenomic analysis of hypolipidemic effects of Agastache rugosa essential oils in HepG2 cells and C57BL/6 mice. Food Sci. Biotechnol. 2010, 19, 219-227.

36. Mo, J.X.; Ma, L. Volatile oil of Herba agastache in various growth periods and different parts by GC-MS. Chin. J. Pharm. 2011, 42, 268-270.

37. Kim, S.I.; Park, C.; Ohh, M.H.; Cho, H.C.; Ahn, Y.J. Contact and fumigant activities of aromatic plant extracts and essential oils against Lasioderma serricorne (Coleoptera: Anobiidae). J. Stored Prod. Res. 2003, 39, 11-19.

38. Kim, S.I.; Roh, J.Y.; Kim, D.H.; Lee, H.S.; Ahn, Y.J. Insecticidal activities of aromatic plant extracts and essential oils against Sitophilus oryzae and Callosobruchus chinensis. J. Stored Prod. Res. 2003, 39, 293-303.

39. Wilson, L.A.; Senechal, N.P.; Widrlechnerr, M.P. Headspace analysis of the volatile oils of Agsstache. J. Agric. Food Chem. 1992, 40, 1362-1366.

40. Yue, J.L.; Pan, X.F.; Wang, J.C. Chemical constituents of essential oil of Agastache rugosa of northeast China. J. Northeast Forestry Univ. 1998, 26, 72-74.

41. Wang, D.M.; Yang, D.B.; Wang, F.S.; Wu, H.Y.; Gu, S.Y. Chemical constituent of Agastache. rugosa essential oils and physical forms of Agastache rugosa. Chin. Tradit. Herb. Drugs 2005, 36, 1302-1303.

42. Mo, J.X.; Jiang, C.; Zhang, X.Y. Studies on characteristics of volatile oil and micro-identification between Herba Pogostamonis and Herba Agastachis Rugosae. J. Chin. Med. Mater. 2009, 32, $1675-1677$.

43. Fujita, S.; Fujita, Y. Miscellaneous contributions to essential oils of the plants from various territories. XXXIII. Essential oil of Agastache rugosa. Yakugaku Zasshi 1973, 93, 1679-1681.

44. Park, I.K.; Kim, J.; Lee, S.G.; Shin, S.C. Nematicidal activity of plant essential oils and components from ajowan (Trachyspermum ammi), allspice (Pimenta dioica) and litsea (Litsea cubeba) essential oils against pine wood nematode (Bursaphelenchus xylophilus). J. Nematol. 2007, 39, 275-279.

45. Ntalli, N.G.; Ferrari, F.; Giannakou, I.; Menkissoglu-Spiroudi, U. Phytochemistry and nematicidal activity of the essential oils from 8 Greek Lamiaceae aromatic plants and 13 terpene components. J. Agric. Food Chem. 2010, 58, 7856-7863.

46. Ntalli, N.G.; Ferrari, F.; Giannakou, I.; Menkissoglu-Spiroudi, U. Synergistic and antagonistic interactions of terpenes against Meloidogyne incognita and the nematicidal activity of essential oils from seven plants indigenous to Greece. Pest. Manag. Sci. 2011, 67, 341-351. 
47. Abdel-Rahman, F.H.; Alaniz, N.M.; Saleh, M.A. Nematicidal activity of terpenoids. J. Environ. Sci. Health 2013, 48B, 16-22.

48. Adams, R.P. Identification of Essential Oil Components by Gas Chromatography/Quadrupole. Mass Spectroscopy; Allured: Carol Stream, IL, USA, 2007.

49. Mohottalage, S.; Tabacchi, R.; Guerin, P.M. Components from Sri Lankan Piper betel L. leaf oil and their analogues showing toxicity against the housefly, Musca domestica. Flav. Fragr. J. 2007, 22, 130-138.

50. Miyazawa, M.; Kohno, G. Suppression of chemical mutagen-induced SOS response by allylbenzen from Asiasarum heterotropoides in the Salmonella typhimurium TA1535/pSK1002 umu test. Nat. Prod. Res. 2005, 19, 29-36.

51. Sakuma, M. Probit analysis of preference data. Appl. Entomol. Zool. 1998, 33, 339-347.

Sample Availability: Samples of the crude extracts and pure compounds are available from the authors.

(C) 2013 by the authors; licensee MDPI, Basel, Switzerland. This article is an open access article distributed under the terms and conditions of the Creative Commons Attribution license (http://creativecommons.org/licenses/by/3.0/). 